B. ALI*,***, S.H. CHOI*,**, S.J. SEO*, D.Y. MAENG****, C.G. LEE*****, T.S. KIM*,***\#, K.T. PARK*\#

\title{
CARBON CO-DEPOSITION DURING GAS REDUCTION OF WATER-ATOMIZED Fe-Cr-Mo POWDER
}

\begin{abstract}
The water atomization of iron powder with a composition of $\mathrm{Fe}-3 \mathrm{Cr}-0.5 \mathrm{Mo}(\mathrm{wt} . \%)$ at $1600^{\circ} \mathrm{C}$ and 150 bar creates an oxide layer, which in this study was reduced using a mixture of methane $\left(\mathrm{CH}_{4}\right)$ and argon $(\mathrm{Ar})$ gas. The lowest oxygen content was achieved with a $100 \mathrm{cc} / \mathrm{min}$ flow rate of $\mathrm{CH}_{4}$, but this also resulted in a co-deposition of carbon due to the cracking of $\mathrm{CH}_{4}$. This carbon can be used directly to create high-quality, sinter hardenable steel, thereby eliminating the need for an additional mixing step prior to sintering. An exponential relationship was found to exist between the $\mathrm{CH}_{4}$ gas flow rate and carbon content of the powder, meaning that its composition can be easily controlled to suit a variety of different applications.
\end{abstract}

Keywords: Water atomization, Fe-based powder, Oxide reduction, Powder metallurgy, Sinter-hardening alloys

\section{Introduction}

The relative abundance and low cost of iron (Fe) already makes it an essential element in daily life, but with increasing advancements in the field of powder metallurgy, Fe-based powders are becoming increasingly used in powder metal processing, welding rods, medicine, wastewater treatment and food production. Most iron powder is used in the production of high-strength steel components, which typically rely on alloying elements such as nickel (Ni), copper $(\mathrm{Cu})$ and molybdenum (Mo) for their strength [1-2]. However, the high cost of these traditional alloying elements has created a need for cheap and efficient alternatives in order to reduce overall product costs. One such alternative is chromium (Cr), which is low in cost, relatively abundant, easy to recycle and offers good resistance to temper softening [1-3]. It is also particularly effective in improving sinter-hardenability [4], which is a process of transforming the whole part or some specific region to martensite by controlling the cooling rate during sintering. This offers many economic benefits as a onestep manufacturing process for achieving a good combination of strength, toughness and hardness [4]. Yet despite all these benefits associated with $\mathrm{Cr}$, it is not currently being used to its fullest potential because of its very high affinity for oxygen [1-5].

The cheapest and most common method for the production of iron and steel powders is water atomization, which offers the important benefit of producing powders with an irregular shape. This facilitates powder compaction, gives good green body strength and makes the powder suitable for near-net shaping of components [6]. However, the interaction of molten metal droplets with water or steam inevitably creates a surface oxide layer during atomization [6-7], and so subsequent reduction is needed to obtain high-purity powder. In this pre-alloyed state, $\mathrm{Cr}$ is usually present in solid solution with iron, and so its activity is roughly equal to its content [5].

The reduction of Fe oxides in a reducing gas environment has been widely studied due to its economic and industrial importance, with a number of studies looking at the kinetics of reduction with $\mathrm{H}_{2}$ [8-14], $\mathrm{CO}$ [13-16] and $\mathrm{CH}_{4}$ [17-20] gas. In a previous study, we briefly discussed the reduction of Fe-based oxides in an environment of $\mathrm{H}_{2}, \mathrm{CO}$ and $\mathrm{CH}_{4}$ [21], and so the present study specifically focuses on the reduction of Cr-based oxides using $\mathrm{CH}_{4}$ gas and the carbon that is co-deposited during reduction. Studies by Ostrovski et al [22] into the reduction of $\mathrm{Cr}_{2} \mathrm{O}_{3}$ using $\mathrm{CH}_{4}$ gas mixtures found that the extent of reduction increases with reduction temperature and $\mathrm{CH}_{4}$ content. Ebrahimi-Kahrizsangi et al. [23] have also shown that the minimum temperature needed for the conversion of $\mathrm{Cr}_{2} \mathrm{O}_{3}$ to $\mathrm{Cr}_{3} \mathrm{C}_{2}$ in a $30 \% \mathrm{CH}_{4}$ gas mixture is $850^{\circ} \mathrm{C}$. Similarly, Khoshandam et al. [24] have demonstrated that there is negligible carbon deposition during the conversion of $\mathrm{Cr}$ oxides to carbides in a $\mathrm{CH}_{4}$ atmosphere, at least within a temperature range of $870-975^{\circ} \mathrm{C}$. These previous studies used gas mixtures composed of $\mathrm{CH}_{4}, \mathrm{H}_{2}$ and Ar, and mostly concerned the reduction of a single oxide of a given metal.

\footnotetext{
* KOREA INSTITUTE FOR RARE METALS, KOREA INSTITUTE OF INDUSTRIAL TECHNOLOGY, INCHEON, SOUTH KOREA

** DEPARTMENT OF ADVANCED MATERIALS ENGINEERING, IN-HA UNIVERSITY, INCHEON, SOUTH KOREA

*** CRITICAL MATERIALS AND SEMICONDUCTOR PACKAGING ENGINEERING, UNIVERSITY OF SCIENCE AND TECHNOLOGY, DAEJEON, SOUTH KOREA

**** SAMSUNG ELECTRO-MECHANICS CO. LTD, SOUTH KOREA.

***** ADVANCED MATERIALS \& PROCESSING CENTER, INSTITUTE FOR ADVANCED ENGINEERING, YONGIN-SI, SOUTH KOREA

Corresponding authors: ktpark@kitech.re.kr and tskim@kitech.re.kr
} 
The present study concerns powder particles with a surface layer that is composed of a number of different oxides of $\mathrm{Fe}$ and $\mathrm{Cr}$, rather than just one. For this, a Fe-based powder with a composition of $\mathrm{Fe}-3 \mathrm{Cr}-0.5 \mathrm{Mo}$ (in wt.\%) was fabricated, and any surface oxides produced during water atomization were reduced in a gas environment. Special attention was given to the reduction of Cr-based oxides by using a mixture of $\mathrm{CH}_{4}$ and $\mathrm{Ar}$. At the experimental temperature used $\left(900^{\circ} \mathrm{C}\right)$, the $\mathrm{CH}_{4}$ decomposes into $\mathrm{C}$ and $\mathrm{H}_{2}$ gas according to following Eq. (1):

$$
\begin{gathered}
\mathrm{CH}_{4}(\mathrm{~g}) \rightleftarrows \mathrm{C}(\mathrm{s})+2 \mathrm{H}_{2}(\mathrm{~g}) \\
\Delta \mathrm{G}_{900^{\circ} \mathrm{C}}^{0}=-38.029 \mathrm{~kJ} / \mathrm{mol}
\end{gathered}
$$

This $\mathrm{H}_{2}$ gas that is generated helps to reduce the oxides, and so no extra addition of $\mathrm{H}_{2}$ was considered necessary. However, as using $\mathrm{CH}_{4}$ for reduction does result in excess carbon being deposited onto the powder, the effect of the gas flow rate on the deposited carbon was studied to develop a mathematical relationship for controlling the carbon content of the final product. Using this, high-carbon alloy powders can be produced directly without any further carbon addition, and once sintered can be used to create high-strength steel parts and wear resistant hardfacing coatings for various applications subject to harsh abrasive conditions, such as automobiles, hard-cased gears and tooling equipment.

\section{Experimental procedure}

A mother alloy with a composition of $\mathrm{Fe}-3 \mathrm{Cr}-0.5 \mathrm{Mo}$ (wt.\%) was fabricated in an electric arc furnace, melted at $1720^{\circ} \mathrm{C}$, and then atomized by a stream of water using a pressure of $15 \mathrm{MPa}$ and a melt orifice diameter of $5 \mathrm{~mm}$. Once the atomized powder was collected and dried, a $20 \mathrm{~g}$ sample was placed inside alumina boat and loaded into quartz tube under a vacuum of $6.5 \times 10^{-2}$ Torr. This was placed into a horizontal vacuum-tube furnace, which was then purged with Ar gas (purity $>99.99 \%$ ) for around 40 minutes. A mixture of $\mathrm{CH}_{4}$ and $\mathrm{Ar}$ gas with different flow rates was then introduced for reduction of the atomized powder. The different gas mixtures used are listed in Table 1 along with the corresponding gas flow rates and experimental parameters followed.

TABLE 1

\begin{tabular}{|c|c|c|c|c|c|c|}
\hline & $\underbrace{0}_{F}$ & 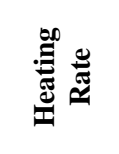 & 曾 弟 & 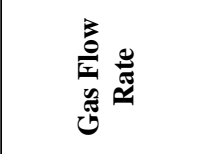 & 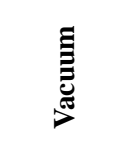 & 总 \\
\hline 1 & \multirow{3}{*}{$900^{\circ} \mathrm{C}$} & \multirow{3}{*}{$5^{\circ} \mathrm{C} / \mathrm{min}$} & \multirow{3}{*}{$1.5 \mathrm{~h}$} & $\begin{array}{l}\mathrm{CH}_{4}-100 \\
\mathrm{cc} / \mathrm{min}\end{array}$ & \multirow{3}{*}{$\begin{array}{c}6.5 \times 10^{-2} \\
\text { torr }\end{array}$} & \multirow{3}{*}{$\begin{array}{l}\text { Total flow } \\
\text { rate was } \\
100 \mathrm{cc} / \mathrm{min} \\
\text { in every } \\
\text { condition }\end{array}$} \\
\hline 2 & & & & $\begin{array}{l}\mathrm{CH}_{4}-50 \mathrm{cc} / \mathrm{min} \\
+\mathrm{Ar}-50 \mathrm{cc} / \mathrm{min}\end{array}$ & & \\
\hline 3 & & & & $\begin{array}{l}\mathrm{CH}_{4}-20 \mathrm{cc} / \mathrm{min} \\
+\mathrm{Ar}-80 \mathrm{cc} / \mathrm{min}\end{array}$ & & \\
\hline
\end{tabular}

Gas composition and experimental parameters used for reduction
Different qualitative and quantitative techniques were used to characterize the initial and final materials. Inductively coupled plasma mass spectroscopy (ICP-MS) was used for chemical analysis of the mother alloy, while the morphology and chemical composition of the powders was analyzed by field emission-scanning electron microscopy (FE-SEM) and energy dispersive spectroscopy (EDS), respectively. The composition of the surface oxide and its depth profile were analyzed by auger electron spectroscopy (AES). Phase identification of the atomized and reduced powder samples was performed by X-ray diffraction (XRD) analysis with $\mathrm{Cu}-\mathrm{K} \alpha$ radiation. The oxygen and carbon content of the reduced powder was estimated by nitrogen/oxygen and carbon/sulfur analysis, respectively. The standard Gibbs free energy variation with temperature during the reduction of $\mathrm{Cr}$ oxides was calculated with the help of HSC Chemistry [24] software.

\section{Results and Discussion}

\subsection{Atomized powders}

The ICP analysis of the mother alloy, the results of which are shown in Table 2, showed that the concentration of elements was very homogenous and close to the starting composition. After atomization, average oxygen content of as-atomized powder was found to be 2.09 wt.\%. Pseudo-binary phase diagram of a $\mathrm{Fe}-3 \mathrm{Cr}-0.5 \mathrm{Mo}$ and $\mathrm{H}_{2} \mathrm{O}$ system showed that three kinds of oxides exist in the high temperature, low $\mathrm{H}_{2} \mathrm{O}$ concentration region, namely: $\mathrm{AB}_{2} \mathrm{O}_{4}$-spinel $\left(\mathrm{Fe}_{3} \mathrm{O}_{4}, \mathrm{FeO} \cdot \mathrm{Cr}_{2} \mathrm{O}_{3}\right)$, MeO-type monoxide $(\mathrm{FeO})$, and $\mathrm{Mo}$ oxide $\left(\mathrm{MoO}_{2}\right)$. At high temperature, $\mathrm{FeO}$ and $\mathrm{AB}_{2} \mathrm{O}_{4}$-spinel $\left(\mathrm{Fe}_{3} \mathrm{O}_{4}\right)$ are the dominant phases, whereas $\mathrm{Fe}_{2} \mathrm{O}_{3}$ is the dominant oxide at low temperature and high concentrations of $\mathrm{H}_{2} \mathrm{O}$. After atomization, the powder consists of $\mathrm{Fe}, \mathrm{Fe}_{3} \mathrm{O}_{4}$ and $\mathrm{FeO}$ phases, as can be seen from the XRD result in Figure 1 [21].

TABLE 2

ICP analysis of mother alloy

\begin{tabular}{|c|c|c|}
\hline \hline \multirow{2}{*}{ Element (nm) } & \multicolumn{2}{|c|}{ Concentration (Fe-3Cr-0.5Mo) } \\
\cline { 2 - 3 } & Weight (\%) & Atomic \% \\
\hline $\operatorname{Cr}(283.5)$ & 2.99 & 3.11 \\
\hline $\mathrm{Fe}(259.9)$ & 96.49 & 96.65 \\
\hline $\operatorname{Mo}(202.0)$ & 0.52 & 0.24 \\
\hline
\end{tabular}

Reduction process follows different chemical pathways based on the reduction temperature. At low temperatures (below $570^{\circ} \mathrm{C}$ ) reduction proceeds in single step from $\mathrm{Fe}_{3} \mathrm{O}_{4}$ to $\mathrm{Fe}$ because $\mathrm{FeO}$ is not stable below this temperate, whereas above this temperature, reduction proceeds in two steps from $\mathrm{Fe}_{3} \mathrm{O}_{4}$ to $\mathrm{FeO}$ and then to $\mathrm{Fe}[21,26]$. 


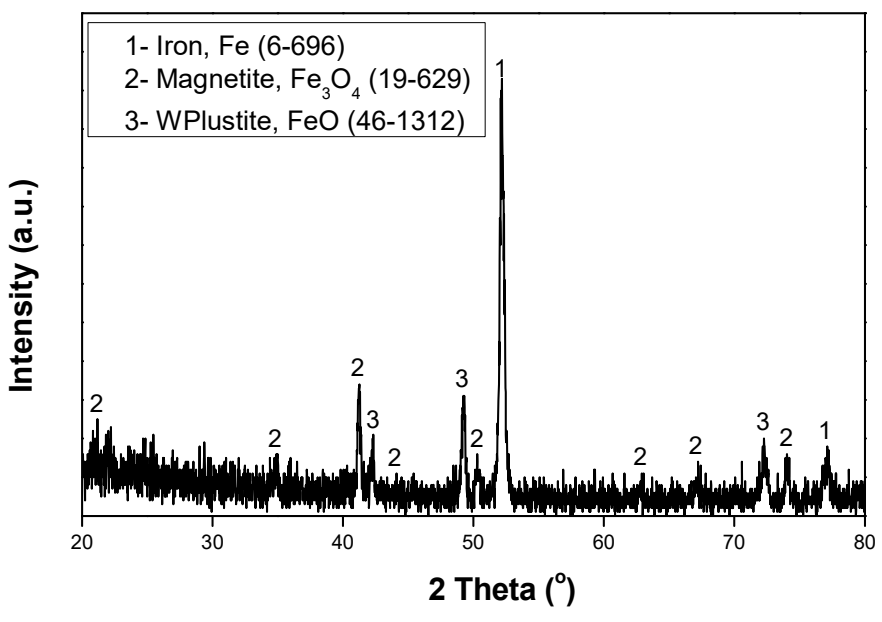

Fig. 1. XRD analysis result of as-atomized powder showing three distinct phases of $\mathrm{Fe}, \mathrm{Fe}_{3} \mathrm{O}_{4}$ and $\mathrm{FeO}$ present in the powder [20]

\subsection{Thermodynamics of chromium oxide reduction}

As mentioned earlier, the atomized powders were predicted to contain $\mathrm{FeO}, \mathrm{Fe}_{3} \mathrm{O}_{4}$ and complex $\mathrm{Cr}$ oxides $\left(\mathrm{Cr}_{2} \mathrm{O}_{3}, \mathrm{FeO}\right.$. $\mathrm{Cr}_{2} \mathrm{O}_{3}$ ). Although the formation of $\mathrm{Cr}$ oxides is unlikely when in a prealloyed state the possibility does still exist, and so the thermodynamics of $\mathrm{Cr}_{2} \mathrm{O}_{3}$ and $\mathrm{FeO} . \mathrm{Cr}_{2} \mathrm{O}_{3}$ reduction were studied. Only $\mathrm{CH}_{4}$ gas was considered as a reductant, as our previous study demonstrated that this gives the optimum oxygen value and helps convert $\mathrm{Cr}_{2} \mathrm{O}_{3}$ to carbide by the following reaction Eq. (2) [27-29]:

$$
\mathrm{Cr}_{2} \mathrm{O}_{3}+13 / 3 \mathrm{CH}_{4}=2 / 3 \mathrm{Cr}_{3} \mathrm{C}_{2}+3 \mathrm{CO}+26 / 3 \mathrm{H}_{2}
$$

Thus, $\mathrm{CH}_{4}$ gas supplies carbon that helps convert the oxide into a carbide through diffusion. However, this represents a complicated and complex process, as at temperatures $>570^{\circ} \mathrm{C}$ the decomposition of $\mathrm{CH}_{4}$ into $\mathrm{H}_{2}$ and $\mathrm{CO}$ becomes feasible. Read et al. [28] studied the reduction of $\mathrm{Cr}_{2} \mathrm{O}_{3}$ with $\mathrm{CH}_{4}$ and found that this decomposition causes reduction to follow a path from Eq. (3) to (6) as:

$$
\begin{gathered}
13 \mathrm{CH}_{4}=13 \mathrm{C}+26 \mathrm{H}_{2} \\
3 \mathrm{Cr}=\mathrm{O}_{3}+9 \mathrm{H}_{2}=6 \mathrm{Cr}+9 \mathrm{H}_{2} \mathrm{O} \\
6 \mathrm{Cr}+4 \mathrm{C}=2 \mathrm{Cr}_{3} \mathrm{C}_{2} \\
9 \mathrm{H}_{2} \mathrm{O}+9 \mathrm{C}=9 \mathrm{H}_{2}+9 \mathrm{CO}
\end{gathered}
$$

Qayyum and Reave [29], on the other hand, suggested that at low temperatures chromite is reduced by the Eq. (7):

$$
\begin{gathered}
\text { 3FeO. } \mathrm{Cr}_{2} \mathrm{O}_{3}+17 \mathrm{CH}_{4}=\mathrm{Fe}_{3} \mathrm{C}+2 \mathrm{Cr}_{3} \mathrm{C}_{2}+ \\
+12 \mathrm{CO}+34 \mathrm{H}_{2}
\end{gathered}
$$

Whereas at high temperature, the reaction follows chemical pathway from Eq. (8) to (12) as shown below:

$$
\begin{gathered}
17 \mathrm{CH}_{4}=17 \mathrm{C}+34 \mathrm{H}_{2} \\
3 \mathrm{FeO} . \mathrm{Cr}_{2} \mathrm{O}_{3}+12 \mathrm{H}_{2}=6 \mathrm{Cr}+3 \mathrm{Fe}+12 \mathrm{H}_{2} \mathrm{O}
\end{gathered}
$$

$$
\begin{gathered}
6 \mathrm{Cr}+4 \mathrm{C}=2 \mathrm{Cr}_{3} \mathrm{C}_{2} \\
3 \mathrm{Fe}+\mathrm{C}=\mathrm{Fe}_{3} \mathrm{C} \\
12 \mathrm{H}_{2} \mathrm{O}+12 \mathrm{C}=12 \mathrm{H}_{2}+12 \mathrm{CO}
\end{gathered}
$$

According to Anacleto et al. [27], the reduction of Cr oxides to metallic $\mathrm{Cr}$ with $\mathrm{H}_{2}$ or $\mathrm{CO}$ needs a much higher temperature, especially $\mathrm{CO}$ gas addition of which retards the reduction rather than promoting it. This implies that $\mathrm{CH}_{4}$ has greater potential for the economic reduction of $\mathrm{Cr}$ oxides. For this reason, a mixture of $\mathrm{CH}_{4}$ and $\mathrm{Ar}$ was used in this study.

\subsection{AES analysis}

The AES spectrum of the as-atomized Fe-3Cr-0.5Mo powder (mean size: $50.32 \mu \mathrm{m}$ ) has been shown in Figure 2. The spectrum shows main peaks for $\mathrm{Fe}, \mathrm{Cr}$, Mo and $\mathrm{O}$. The strength of the latter indicates that the surface of the powder was covered with an oxide layer, which likely consisted mostly of Fe oxides based on the strength of the Fe peak. The minute Cr peak does, however, suggest that at least some $\mathrm{Cr}$ oxide was also present, with the lower peak intensity likely caused by interference from the $\mathrm{O}$ and Fe peaks [6]. Depth profiling by AES can be used to determine the extent to which this oxide layer extends from the surface, with Figure 3 showing the change in $\mathrm{Fe}, \mathrm{O}$ and $\mathrm{Cr}$ with analysis time and particle depth. This demonstrates that the concentration of $\mathrm{Fe}$ increases with depth, while the concentration of $\mathrm{O}$ and $\mathrm{Cr}$ decreases, thus indicating that only a surface layer of oxide is present. This oxide layer is likely a complex Cr-based oxide such as $\mathrm{Cr}_{2} \mathrm{O}_{3}$ or $\mathrm{FeO} . \mathrm{Cr}_{2} \mathrm{O}_{3}$, as the AES results confirm the presence of both $\mathrm{Fe}$ and $\mathrm{Cr}$ on the surface of the as-atomized particles.

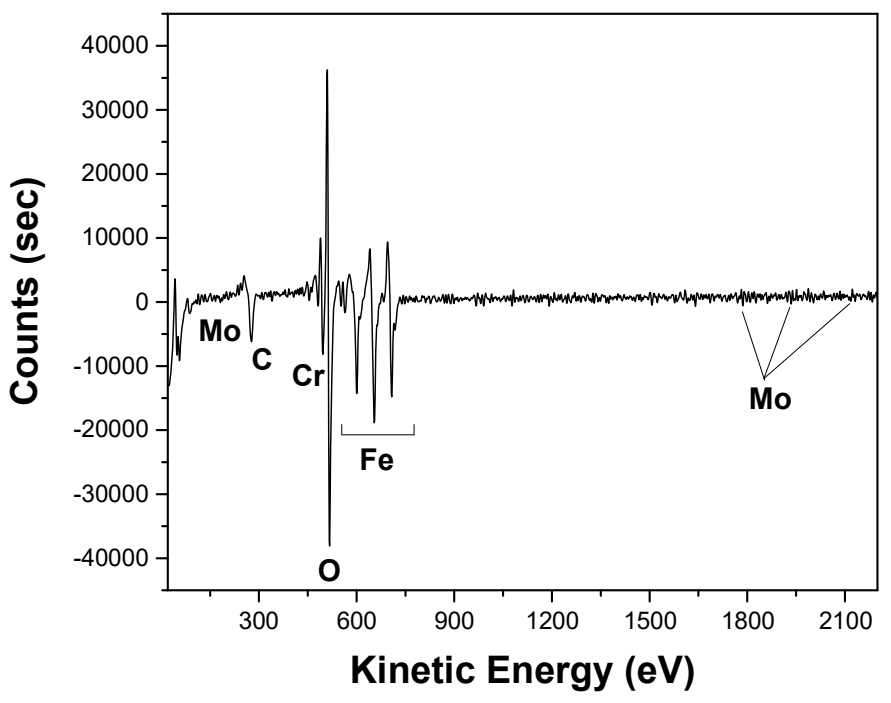

Fig. 2. AES spectrum for as-atomized Fe-3Cr-0.5Mo powder

Powders of Fe alloyed with $\mathrm{Cr}$ are typically soft annealed at $800-1000^{\circ} \mathrm{C}$ under a $\mathrm{H}_{2}$ atmosphere in order to minimize $\mathrm{O}_{2}$ and prevent the formation of Fe oxides [30]. This use of $\mathrm{H}_{2}$ as 


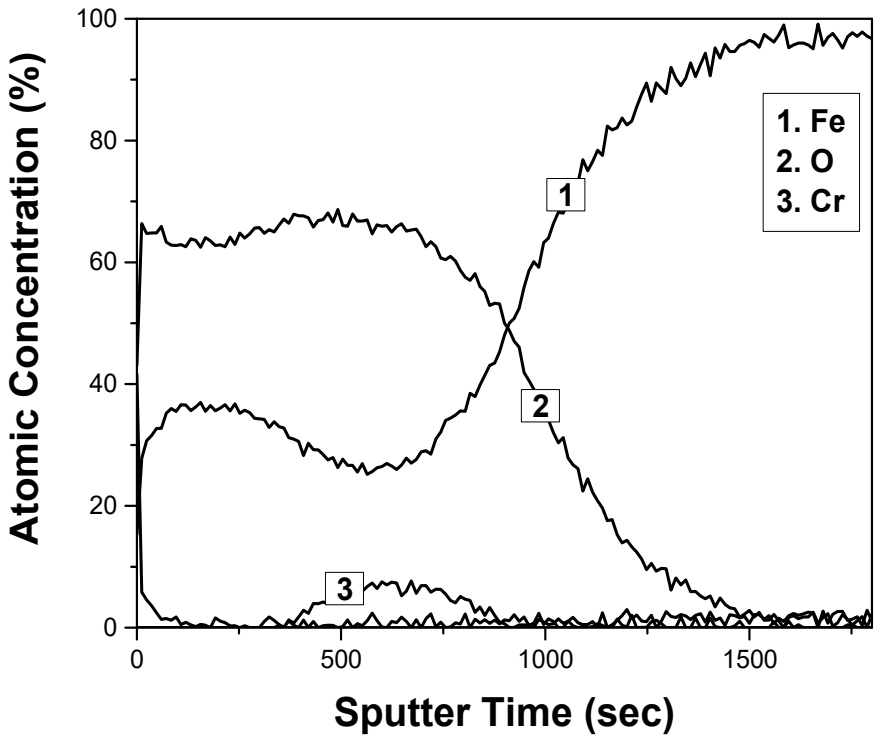

Fig. 3. AES spectrum sputter time and atomic concentration for asatomized $\mathrm{Fe}-3 \mathrm{Cr}-0.5 \mathrm{Mo}$ powder

a reducing agent can, however, produce compact Fe layers that can slow the overall reduction rate [8]. Moreover, the reduction of $\mathrm{Cr}$-based oxides by $\mathrm{H}_{2}$ requires very high temperatures. Figure 4 presents a graph showing the effect of increasing temperature on the Gibbs free energy $\left(\Delta \mathrm{G}^{\circ}\right)$ for the reduction $\mathrm{Cr}_{2} \mathrm{O}_{3}$ with $\mathrm{H}_{2}$ gas. This shows that even at very high temperature, the $\Delta G^{\mathrm{o}}$ value remains positive, indicating that the reaction is not feasible. In this situation $\mathrm{CH}_{4}$ plays a vital role, as Anacleto et al. [27] have shown that it can increase the rate of $\mathrm{Cr}$ oxide reduction by facilitating the formation of $\mathrm{Cr}$ carbides, which are then reduced to $\mathrm{Cr}$ metal by $\mathrm{H}_{2}$. However, as this process results in the deposition of carbon onto the particles, it is necessary to study both the role of $\mathrm{CH}_{4}$ in reduction and its decomposition to carbon.

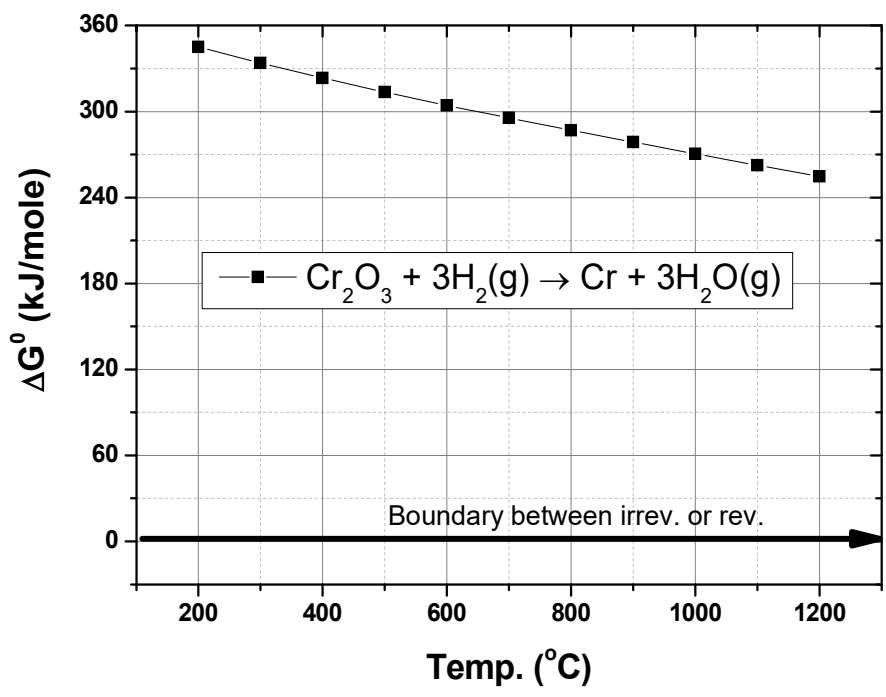

Fig. 4. Gibbs free energy $\left(\Delta \mathrm{G}^{0}\right)$ vs. temperature for the reduction of $\mathrm{Cr}_{2} \mathrm{O}_{3}$ with $\mathrm{H}_{2}$ gas

\subsection{Post reduction}

In the XRD patterns of powders reduced using three different flow rates of $\mathrm{CH}_{4}$ given in Figure 5, two distinct phases (Fe and $\mathrm{Fe}_{3} \mathrm{C}$ ) were detected. The $\mathrm{Fe}_{3} \mathrm{C}$ peak intensity was highest when $100 \mathrm{cc} / \mathrm{min}$ of $\mathrm{CH}_{4}$ was used, and decreased with a decrease in $\mathrm{CH}_{4}$ flow rate. As explained earlier, this $\mathrm{Fe}_{3} \mathrm{C}$ is produced as a result of the decomposition of $\mathrm{CH}_{4}$ into $\mathrm{C}$ and $\mathrm{H}_{2}$ at high temperature. No elemental carbon was detected because this is present in an amorphous state and XRD can only be used for the detection of crystalline materials.

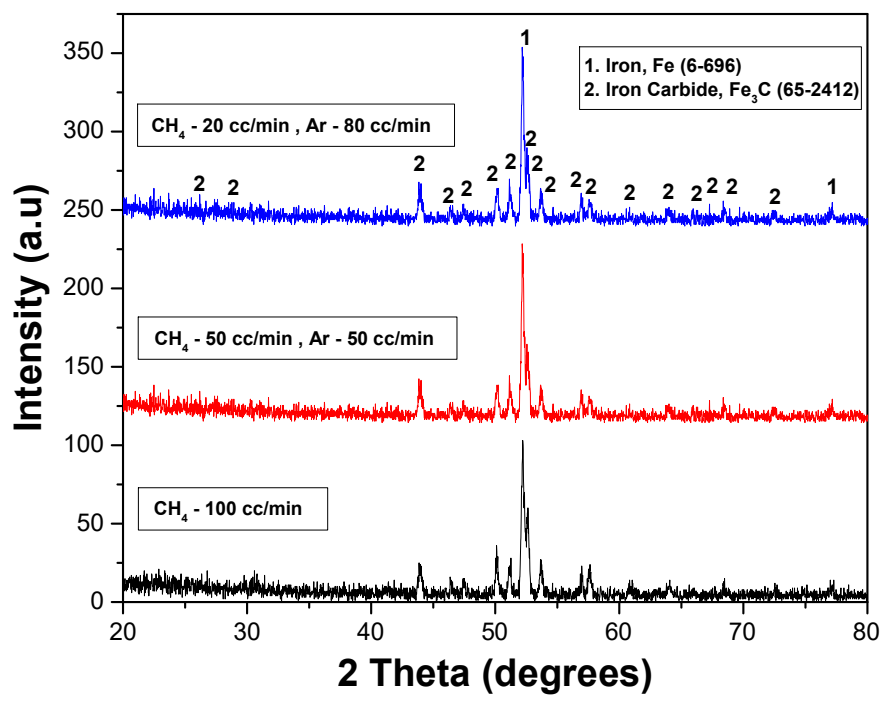

Fig. 5. XRD patterns of powders after reduction with a mixture of $\mathrm{CH}_{4}$ and Ar gas

The results presented in Table 3 show that the lowest $\mathrm{O}$ concentration (0.498 wt\%) and highest C concentration (7.998 wt.\%) occurred in the sample reduced with $100 \mathrm{cc} / \mathrm{min} \mathrm{CH}_{4}$. When compared to the initial $\mathrm{O}$ concentration of the as-atomized pow$\operatorname{der}(2.09 \mathrm{wt} . \%)$, this represents a very promising decrease in the extent of oxidation. Lower $\mathrm{CH}_{4}$ flow rates resulted in a decrease in $\mathrm{C}$ concentration and increase in $\mathrm{O}$ concentration.

Figure 6 presents SEM and EDS analysis results for powders reduced using different flow rates of $\mathrm{CH}_{4}$. It is evident from this that the particles were generally irregular in shape, and were high in carbon due to the decomposition of $\mathrm{CH}_{4}$. The absence of oxygen in the EDS results is promising in terms of achieving reduction. The sample reduced with $100 \mathrm{cc} / \mathrm{min}$ of $\mathrm{CH}_{4}$ had the highest $\mathrm{Cr}$ and $\mathrm{C}$ content, whereas a $20 \mathrm{cc} / \mathrm{min}$ flow rate produced the lowest values, indicating that these values are directly related to the amount of $\mathrm{CH}_{4}$ in the gas mixture used.

Commercially available Fe-based powders need to be mixed with carbon prior to sintering, but as carbon is deposited during reduction with $\mathrm{CH}_{4}$, this can potentially eliminate a step in the process and greatly reduce the cost of manufacturing. The small amount of oxygen still present in the sample (Table 3 ) should be reduced by the deposited carbon during sintering of the powder, as this is normally conducted at temperatures of $1000-1200^{\circ} \mathrm{C}$. The remaining carbon can then form ferrite, austenite and other 

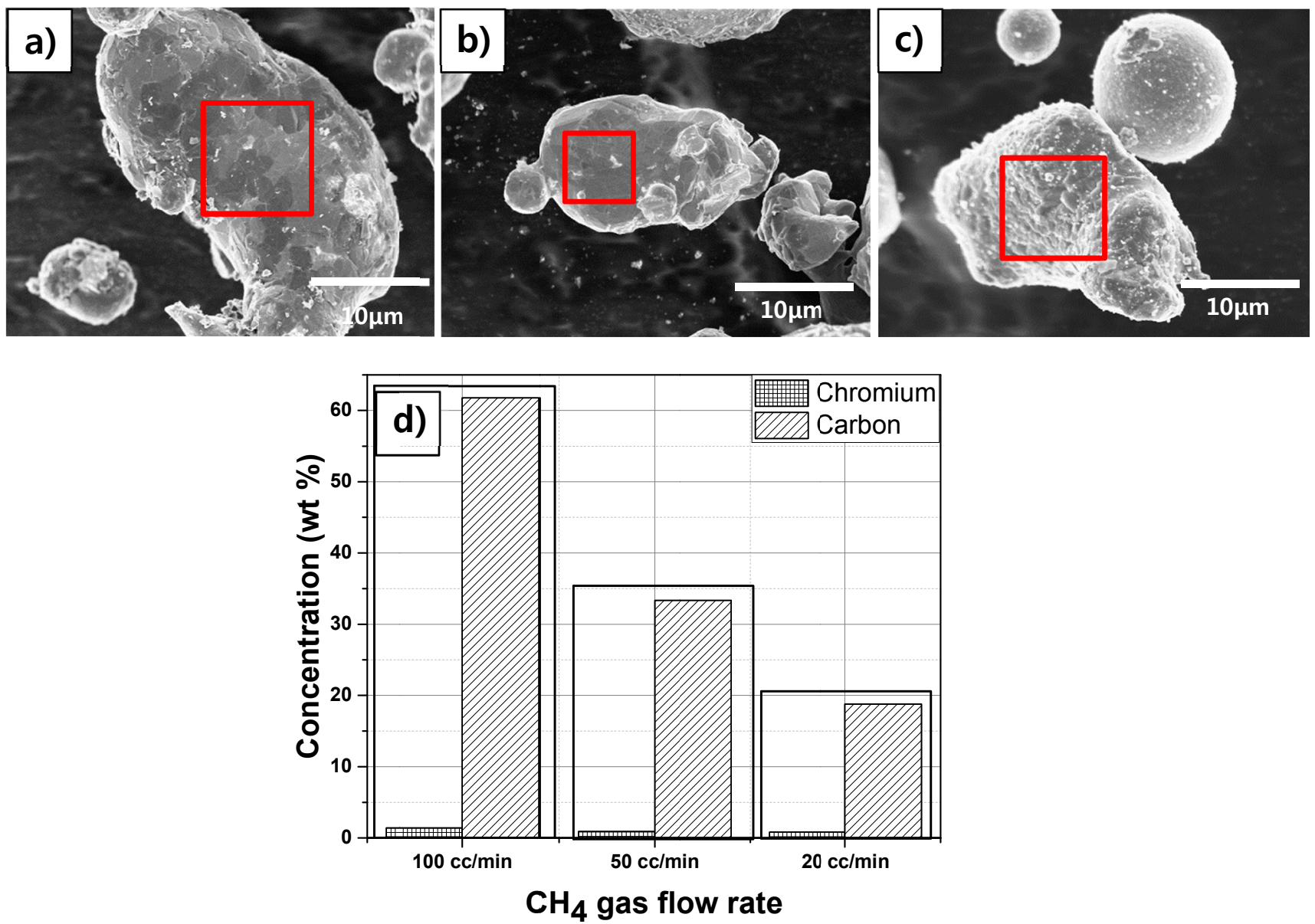

Fig. 6. SEM and EDS analysis results for powders reduced with: a) $100 \mathrm{cc} / \mathrm{min} \mathrm{CH}_{4}$, b) $50 \mathrm{cc} / \mathrm{min} \mathrm{CH}_{4}$ and $50 \mathrm{cc} / \mathrm{min} \mathrm{Ar}$, and c) $20 \mathrm{cc} / \mathrm{min} \mathrm{CH}$ and $80 \mathrm{cc} / \mathrm{min} \mathrm{Ar}$ d) Comparison of $\mathrm{C}$ and $\mathrm{Cr}$ content in highlighted area

steel phases, or very hard carbides like $\mathrm{Fe}_{3} \mathrm{C}, \mathrm{Cr}_{23} \mathrm{C}_{6}$, and $\mathrm{Cr}_{7} \mathrm{C}_{6}$ [31-32]. As these carbide phases should be dispersed inside the microstructure of the sintered steel, they should have a significant effect in terms of increasing the strength, hardness and wear resistance of the final component.

TABLE 3

Carbon and oxygen content of powder reduced at different $\mathrm{CH}_{4}$ flow rates

\begin{tabular}{|c|c|c|}
\hline Gas Flow Rate & Carbon (\%) & Oxygen (\%) \\
\hline $\mathrm{CH}_{4}-100 \mathrm{cc} / \mathrm{min}$ & 7.998 & 0.493 \\
\hline $\mathrm{CH}_{4}-50 \mathrm{cc} / \mathrm{min}, \mathrm{Ar}-50 \mathrm{cc} / \mathrm{min}$ & 5.04 & 0.513 \\
\hline $\mathrm{CH}_{4}-20 \mathrm{cc} / \mathrm{min}, \mathrm{Ar}-80 \mathrm{cc} / \mathrm{min}$ & 3.83 & 0.702 \\
\hline
\end{tabular}

Powders with a high carbon content often have a detrimental effect on the properties of sintered parts (high carbon content induces embrittlement and reduces hardenability [31]), thus making control over the carbon content during reduction by varying the $\mathrm{CH}_{4}$ flow rate is very beneficial from an industrial point of view. The graph of $\mathrm{CH}_{4}$ flow rate and retained carbon content in Figure 7 shows exponential behavior, and so a mathematical expression was derived using the general form of an exponential function $\left(y=a b^{x}\right)$ :

$$
y=(3.19)(1.0092)^{x}
$$

Where in Eq. (13), $y$ is the carbon content of the reduced sample and $x$ is the $\mathrm{CH}_{4}$ gas flow rate. Using this expression, the amount of carbon can be carefully controlled so as to minimize the cost and time of processing.

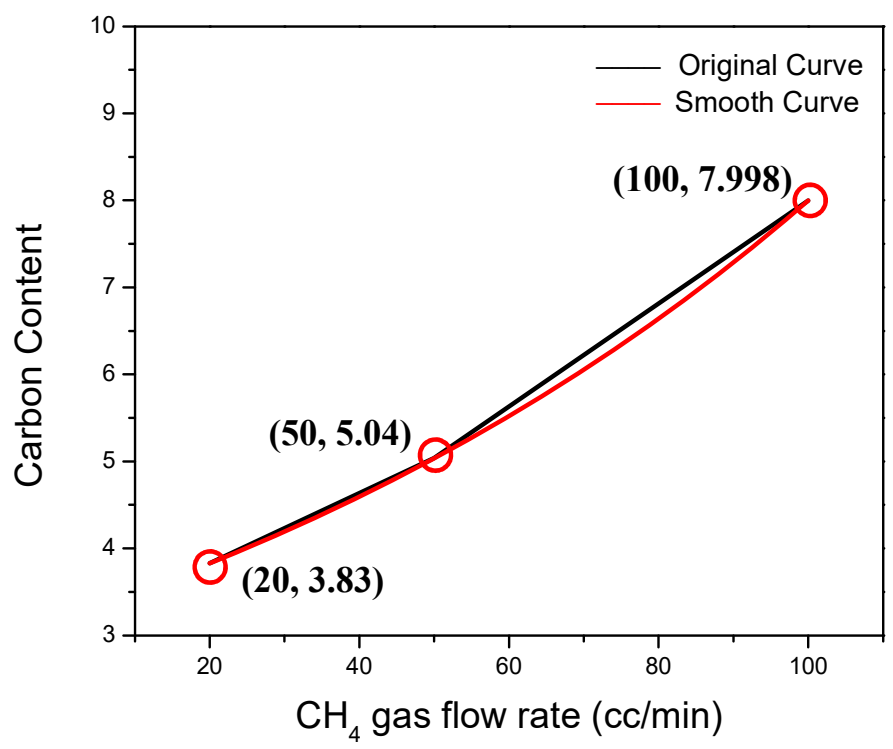

Fig. 7. Curve showing exponential relationship between co-deposited carbon and $\mathrm{CH}_{4}$ gas flow rate 


\section{Conclusions}

A Cr-based prealloyed Fe powder with a composition of Fe-3Cr-0.5Mo was successfully fabricated via water atomization, but found to have a surface oxide layer composed of Fe- and Cr-based oxides. A literature survey revealed that gas mixtures containing $\mathrm{CH}_{4}$ are the most suitable for the reduction of $\mathrm{Cr}$ based oxides, and so a mix of $\mathrm{CH}_{4}$ and $\mathrm{Ar}$ was used to reduce the as-atomized powder at $900^{\circ} \mathrm{C}$. At this temperature $\mathrm{CH}_{4}$ decomposes into $\mathrm{H}_{2}$ and carbon, with the latter converting $\mathrm{Cr}$ oxides into carbides. The $\mathrm{H}_{2}$ then reduces these carbides to metallic $\mathrm{Cr}$. At the same time, excess carbon is co-deposited onto the particle surface during reduction. As the amount of carbon deposited increases exponentially with the $\mathrm{CH}_{4}$ flow rate, it can be easily controlled to provide sufficient carbon for direct sintering. This could eliminate the need to pre-mix powders with carbon prior to sintering, thereby drastically reducing the processing costs and time needed for sintering.

\section{Acknowledgments}

This research was supported by an internal R\&D program of the Korea Institute of Industrial Technology (KITECH), funded by the Ministry of Strategy and Finance, Korea and partially supported by the technology innovation program of the Korea Institute of Energy Technology Evaluation and Planning(KETEP) granted financial resource from the Ministry of Trade, Industry \&Energy, Republic of Korea (No. 20165010100870)

\section{REFERENCES}

[1] B. Hu, A. Klekovkin, D. Milligan, U. Engström, S. Berg, B. Maroli, Properties of high density Cr-Mo pre-alloyed materials high temperature sintered, in: Advances in Powder Metallurgy \& Particulate Materials, Vol. 2, Metal Powder Industries Federation (2004).

[2] M. Hrubovčáková, E. Dudrová, J. Harvanová, Powder Metall. Prog. 11, 115 (2011).

[3] J.M. Torralba, R. de Oro, M. Campos, Mater. Sci. Forum 672, 3-11 (2011).

[4] M.C. Baran, A.H. Graham, A.B. Davala, R.J. Causton, C. Schade, A superior sinter-hardenable material, in: Proceedings of the International Conference on Powder Metallurgy \& Particulate Materials (1999).

[5] E. Hryha, L. Čajková, E. Dudrová, Study of reduction/oxidation processes in Cr-Mo prealloyed steels during sintering by continuous atmosphere monitoring, in: Proceedings of the European Congress \& Exhibition in Powder Metallurgy (2008).

[6] H. Karlsson, L. Nyborg, S. Berg, Powder Metall. 48, 51-58 (2005).

[7] H.M. Shin, K.H. Baik, J. Korean Powder Metall. Inst. 21, 422-28 (2014).

[8] A. Pineau, N. Kanari, I. Gaballah, Thermochim. Acta 447, 89-100 (2006).
[9] M.V.C. Sastri, R.P. Viswanath, B. Viswanatha, Int. J. Hydrogen Energy 7, 951-955 (1982).

[10] H.Y. Lin, Y.W. Chen, C. Li. Thermochim. Acta 400, 61-67 (2003).

[11] D. Wagner, O. Devisme, F. Patisson, D. Ablitzer, A laboratory study of the reduction of iron oxides by hydrogen, in: Advanced Processing of Metals and Materials (Sohn International Symposium) Vol. 2, Thermo and Physicochemical Principles: Iron and Steel Making (2006).

[12] B. Hou, H. Zhang, H. Li, Q. Zhu, Chin. J. Chem. Eng. 20, 10-17 (2012).

[13] E. Kawasaki, J. Sanscrainte, T.J. Walsh, AlChE J. 8, 48-52 (1962).

[14] W.K. Jozwiak, E. Kaczmarek, T.P. Maniecki, W. Ignaczak, W. Maniukiewicz, Appl. Catal. A 326, 17-27 (2007).

[15] K. Mondal, H. Lorethova, E. Hippo, T. Wiltowski, S.B. Lalvani, Fuel Process. Technol. 86, 33-47 (2004).

[16] C.D. Bohnt, J.P. Cleeton, C.M. Miiller, S.A. Scotr, J S. Dennis, Measuring the kinetics of the reduction of iron oxide with carbon monoxide in a fluidized bed, in: Proceedings of the 20th International Conference on Fluidized Bed Combustion (2010).

[17] A. Domşa, L. Szabó, Z. Spîrchez, A. Pálfalvi, The kinetics of direct reduction of iron oxides with methane, in: Modern Developments in Powder Metallurgy, Volume 1: Fundamentals and Methods (1966).

[18] D. Barret, Ind. Eng. Chem. Process Des. Dev. 11, 415-20 (1972).

[19] D. Ghosh, A.K. Roy, A. Ghosh, Trans. Iron Steel lnst. Jpn. 26 186-93 (1986).

[20] A. Steinfeld, A. Frei, P. Kuhn. Metall. Mater. Trans. B 26, 509-15 (2005).

[21] B. Ali, S.H. Choi, S.Y. Kim, J.J. Sim, S.H. Lee, S.J. Seo, T.S. Kim, D.G. Kim, K.M. Lim, T.H. Lee, K.T. Park, Met. Mater. Int. 22, 1073-82 (2016).

[22] O. Ostrovski, A. Jacobs, N. Anacleto, Gregory McKenzie, Reduction of chromium oxide by methane-containing gas, in: Proceedings of the Ninth International Ferroalloys Conference (2001).

[23] R. Ebrahimi-Kahrizsangi, H.M. Zadeh, V. Nemati, Int. J. Refract. Met. Hard Mater 28, 412-415 (2010).

[24] B. Khoshandam, R.V. Kumar, AIChE J. 52, 1094-1102 (2006).

[25] HSC chemistry Software ver. 6.12. Outotec Research, Finland.

[26] R. Longbottom, L. Kolbeinsen, Iron ore Reduction with $\mathrm{CO}$ and H2 Gas Mixtures - Thermodynamic and Kinetic Modelling, in: Proceedings of the $4^{\text {th }}$ Ulcos Seminar (2008).

[27] N. Anacleto, O. Ostrovski, Metal. Mater. Trans B. 35, 609-615 (2004).

[28] P. Read, D. Reeve, J. Walsh, J. Rehder. Can. Met. Q. 13, 587-95 (1974).

[29] M. Qayyum, D. Reeve, Can. Met. Q. 15, 193-200 (1976).

[30] Production of Iron and Steel Powders, Höganäs AB.

[31] M. Maalekian, "The Effects of Alloying Elements on Steels" Institut für Werkstoffkunde, Schweißtechnik und Spanlose Formgebungsverfahren. (2007).

[32] C. Fan, M.C. Chen, W. Wu, Surf. Coat. Technol. 201, 908-912 (2006). 